
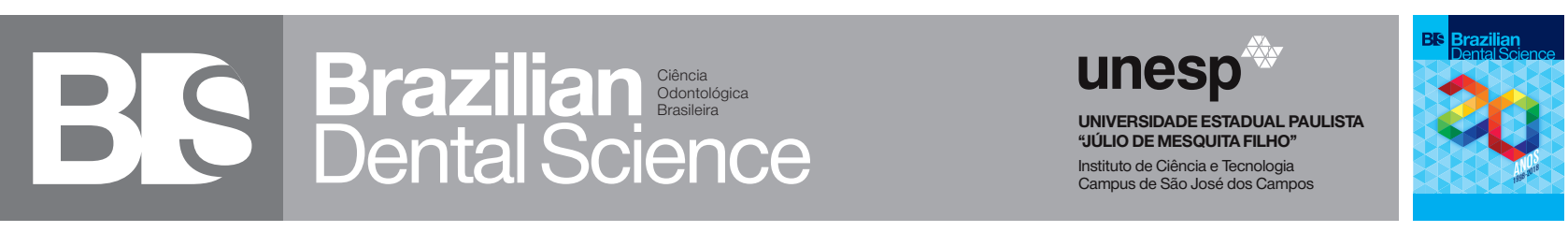

\title{
Evaluation of the mandibular notch angle in three-dimensional virtual models as a parameter for determining age and sexual dimorphism
}

Avaliação do ângulo da incisura mandibular em modelos virtuais tridimensionais como parâmetro para estimativa de idade e dimorfismo sexual

Ana Amélia BARBIERI ${ }^{1}$, Daniela BONFIETTE ${ }^{1}$, Jeferson Lopes Campos BORGES ${ }^{1}$, Eurico OLIVEIRA ${ }^{2}$, Afonso Celso Souza ASSIS ${ }^{1}$, Luís Roberto MANHÃES JÚNIOR ${ }^{1}$, Sérgio Lúcio Pereira de Castro LOPES ${ }^{1}$

1 - São Paulo State University (Unesp) - Institute of Science and Technology, São José dos Campos - Department of Diagnosis and Surgery - SP - Brazil.

2 - São Paulo State University (Unesp) - Institute of Science and Technology, São José dos Campos - Department of Biosciences and Oral Diagnosis - SP - Brazil.

\section{ABSTRACT}

Objective: The objective of this study was to analyze the opening of the mandibular notch angle (MNA) as a possible tool for predicting sex and estimating age so as to contribute to forensic anthropological studies. Material and Methods: For this, 60 cone beam computed tomographs (CBCT) belonging to the UNESP ICT Radiology archive, were selected: 5 female and 5 male for each decade of life, beginning on twenties until there seventies, totalizing 30 female and 30 male. Three-dimensional models were generated for each exam and measurements were performed with three-dimensional angular measuring tools using OnDemand 3D software (Cybermed Inc., Tustin, CA, USA) on the MNA. The MNA was measured considering the posteriormost portion of the coronoid process, the lowest point of the mandibular notch, and the anteriormost point of the condylar process of the mandible. The MannWhitney test was performed with the intention of establishing the possible comparative relationships between the values of angular measurements and sex. Results: No statistically significant differences were found between mandibular incision measurements in both sexes, as well as when comparing the angular measurements of the mandibular incisions and the different age groups studied, when a Kruskall-Wallis test was performed. Conclusion: It was concluded that the structure being evaluated did not appear to be an instrument capable of contributing to forensic anthropology evaluations.

\section{KEYWORDS}

X-ray computed tomography; Forensic anthropology; Legal dentistry; Determination of age by skeleton; Analysis for determination of sex.

\section{RESUMO}

Objetivo: O objetivo deste estudo foi analisar o ângulo de abertura da incisura mandibular (AIM) como uma possível ferramenta para predição sexual e estimativa de idade, de modo a contribuir com estudos antropológicos forenses. Materiais e Métodos: Para tanto, foram selecionadas 60 tomografias computadorizadas de feixe cônico (TCFC) pertencentes ao arquivo de Radiologia das ICT/UNESP: 30 do sexo feminino e 30 do sexo masculino, contendo 5 exames para cada sexo na $2^{\mathrm{a}}, 3^{\mathrm{a}}, 4^{\mathrm{a}}, 5^{\mathrm{a}}, 6^{\mathrm{a}}$ e $7^{\mathrm{a}}$ décadas de vida. Foram gerados modelos tridimensionais para cada exame e as medições foram realizadas com ferramentas de medição angular tridimensionais usando o software OnDemand 3D (Cybermed Inc., Tustin, CA, EUA) nos AIMs. O AIM foi medido considerando a porção mais posterior do processo coronoide, o ponto mais baixo da incisura mandibular, e o ponto mais anterior do processo condilar da mandíbula. O teste de Mann-Whitney foi realizado com o intuito de estabelecer as possíveis relações comparativas entre os valores das medidas angulares e sexo, que não foram encontradas diferenças estatisticamente significantes entre as medidas de incisão mandibular em ambos os sexos, assim como quando comparamos as medidas angulares da incisões mandibulares e as diferentes faixas etárias estudadas, foi realizado o teste de Kruskall-Wallis. Resultados: Em relação à reprodutibilidade das medidas, verificou-se que houve reprodutibilidade entre as medidas repetidas. Conclusão: Concluiu-se que a estrutura avaliada não parece ser um instrumento capaz de contribuir para as avaliações antropológicas forenses.

\section{PALAVRAS-CHAVE}

Tomografia computadorizada por raios X; Antropología forense; Odontologia legal; Determinação da idade pelo esqueleto; Análise para determinação do sexo. 


\section{INTRODUCTION}

$\mathrm{F}$ orensic anthropology is that part of anthropology that studies humans with the purpose of identifying them by means of their bone structures. This has led to the widespread application of its methods on cadavers that are charred, mutilated, or in advanced states of decomposition, or even in bone fragments [1].

In addition to the collection and analysis of data on the individual, such as those already mentioned (sex, age, height, and biotype), anthropological studies can identify features that suggest habits and verify diseases and injuries. Many of the structural elements of the craniofacial skeleton have been studied and measured as to their dimensions so that they can be used as parameters for estimating the age and sex of individuals, as well as for the identification of corpses.

The forensic anthropological method of estimating age and sex through somatometric measurements of bone structures is widely used, given its mathematical precision and broad analysis of the population used in the studies. However, it should be noted that the effectiveness of somatometry is related to its regional application, due to the mixture of ethnicities and environmental factors that leave specific characteristics in certain populations, causing peculiarities in their measurements and angles $[2,3]$.

Among the various bones and joints of the human skeleton, the temporomandibular joint (TMJ), stands out for its morphofunctional complexity and is often subject to conditions that could lead to the modification of its bone components.

França et al. [4] evalueted Temporomandibular Joint dimensions in virtual three-dimensional models acquired through cone-beam computed tomography as determinants of sexual dimorphism and found significant statistical differences between sexes, with a tendency to greater values in males. However, no studies were found in the literature that utilized Virtual 3D models generated from CTs and that took into account angular mandible measurements and their relationship with age and sex in a given population. For this reason, the angle formed by the posteriormost part of the coronoid process, the lowest point of the mandibular notch, and the anteriormost point of the mandible's condylar process (Mandibular Notch Angle-MNA) were taken in to consideration in this present study.

The advantages of the cone beam computed tomography (CBCT) that made this technique so widely used include a lower dose of radiation when compared with fan beam computed tomography (FBCT), the absence of overlapping images, a high degree of spatial resolution on bone tissues, the possibility of multiplanar reconstructions, the precision of measurements in the images, and the possibility of obtaining real distances between important anatomical structures in the maxillofacial complex. In addition to all these benefits, the CBCT is also able to generate three-dimensional virtual models (3D models) by means of volume rendering, displayed on the computer screen, on which different protocols can be applied for reconstruction in order to emphasize hard and soft tissues, as well as airways in the head and neck region, in addition to the initial volume obtained, all without the need for additional data acquisition. These 3D models constitute a reliable reproduction of the patient's tissues, and can even be printed physically in a process called rapid prototyping.

This study aims to analyze the mandibular notch opening angle (MNA) so as to contribute to the evaluations of forensic 
anthropology in order to estimate age and sex, which would verify the importance of its use.

\section{MATERIAL AND METHODS}

This study was approved by the Human Research Ethics Committee of the Institute of Science and Technology, São Paulo State University.

\subsection{Sample selection and}

Sixty cone beam computed tomographys (CBCT) were selected from the Radiology Clinic from a Brazilian Dental School. At the present study an interest sample belonging to the TCFC exams file was used. As the TCFC exams employ ionizing radiation, it would not be possible or justifiable requiring this kind of exam only for this purpose. Methodology was based in França et al [4]. In addition, as estimation, an IBGE (Brazilian Geography and Statistical Institute) table [5] relating to 2010 demographic sence was applied.

\subsection{Inclusion and exclusion criteria}

All exams evaluated and later selected were scanned using, using I-CAT Next Generation (Imaging Science International, PA, USA), with patients in occlusion (stabilized by an occlusal bite block) FOV of $16 \mathrm{~cm} \mathrm{x}$ $13 \mathrm{~cm}$, covering the temporomandibular joints and the upper portion of the ramus and the entire bilateral mandibular notch in voxels of $0.25 \mathrm{~mm}$.

The sample was composed of 60 conebeam computed tomography (CBCT) exams, with 30 exams from males and 30 from females. These were divided into six (6) age groups: $2^{\text {nd }}, 3^{\text {rd }}, 4^{\text {th }}, 5^{\text {th }}, 6^{\text {th }}$ and $7^{\text {th }}$ decades of life, with each age group composed of 5 exams.
Exams were disregarded if they had no record of both left and right mandibular notches or if they presented with pathologies such as neoplasia, altered development, fractures, or any type of pathological process, as were exams with low quality images that did not allow a perfect visualization of the structures analyzed.

\subsection{Methods}

The selection of the sample was performed by means of an analysis in the software of the XORAN scanning system (Xoran Technologies, Ann Arbor, MI, USA), which meant that they were evaluated on MPR screens (multiplanar reconstructions in sagittal, axial, and coronal planes) in addition to providing information on the sex and age of the individuals of each exam.

Images from each exam were exported in their DICOM format (Digital Imaging and Communication on Medicine) to the OnDemand3 software (Cybermed Inc., Tustin, CA, USA) and viewed in three-dimensions in a 3D module, in bone protocol, for the measurements related to the pre-determined angle: the mandibular notch opening angle (MNA). Using the tool for three-dimensional selection, a volume segmentation of the image was made in order to isolate the upper region of the right and left mandibular rami from each exam. Three-dimensional angular measurements were then made to carry out the following measurements on 3D models: the angle formed which sides corresponded to semi-straight tangents to the sides of mandibular notches (MNA). Initially this angle was traced and then checked, by rotating the $3 \mathrm{D}$ model, as to whether it actually corresponded to the tangents of these sides-if not, it was readjusted to satisfy this condition (Figure 1). 


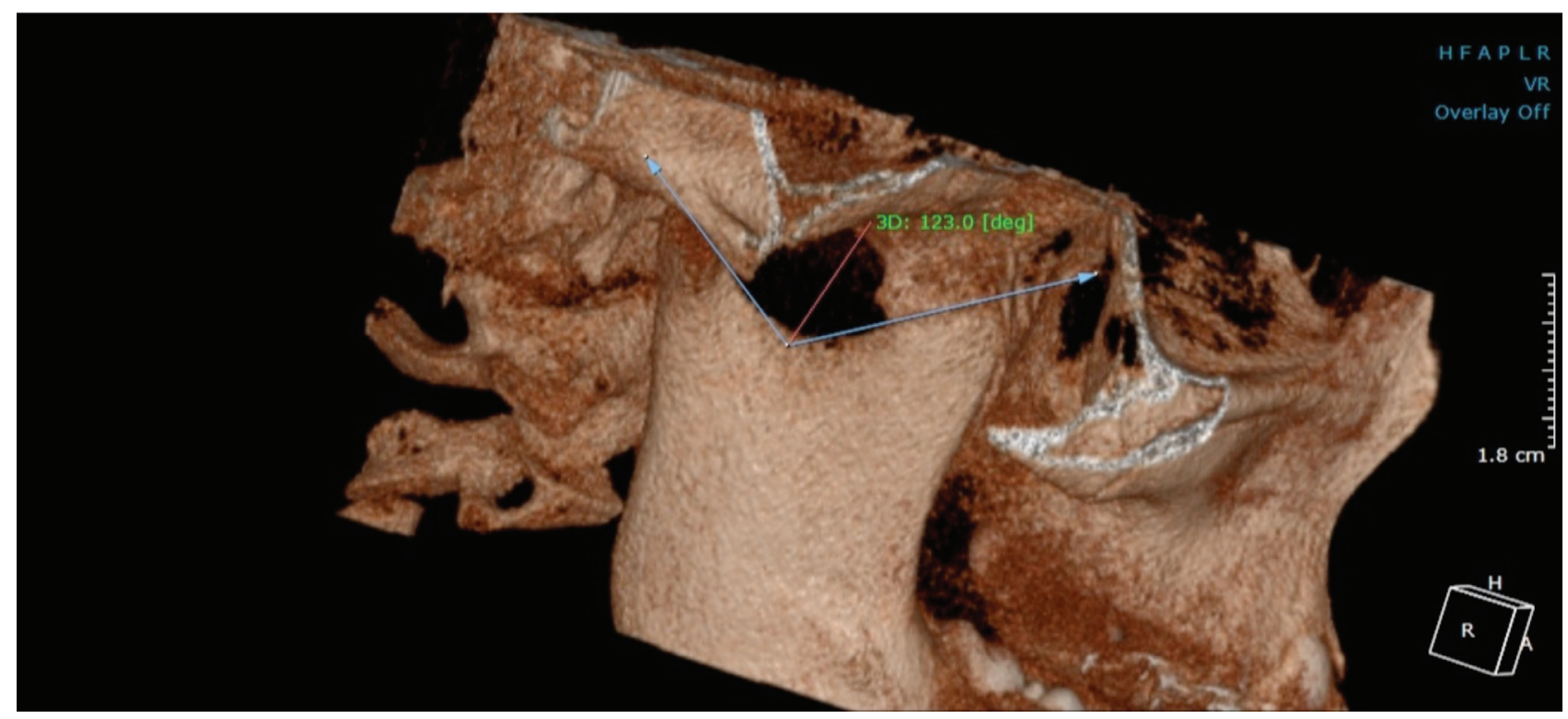

Figure 1-3D virtual model on OnDemand 3D software with measuring of the MNA.

All measurements were made by two previously trained evaluators (oral radiologist, with 05 years of experience in CBCT images). The concordance between the examiners was established by the Intraclass Correlation Coefficient (ICC), obtaining a value of 0.80 , indicating an excellent concordance. For this, measurements were performed in $10.0 \%$ of the sample repeated 24 hours apart. The analyses were made on a 19-inch LCD monitor at the radiology clinic of the University.

The data relating to the measurements obtained in the whole sample as well as age and sex of each exam were tabulated and submitted to descriptive statistics.

\section{RESULTS}

To describe the sample profile according to the variables under study, frequency tables were made of the categorical variables with values for absolute frequency (n) and percentage (\%) (Tables 1 and 2), as well as descriptive statistics of numerical variables with average values, standard deviations, minimum and maximum values, and medians (Table 3).
Table 1- Distribution of the sample in relation to sex

\begin{tabular}{|c|c|c|}
\hline Sex & Frequency & $\%$ \\
\hline Male & 73 & 49.66 \\
\hline Female & 74 & 50.34 \\
\hline Total & 147 & 100.00 \\
\hline
\end{tabular}

Table 2 - Distribution of the sample in relation to sex

\begin{tabular}{|c|c|c|}
\hline Age Group & Frequency & $\%$ \\
\hline 18 to 30 years & 28 & 19.05 \\
\hline 31 to 40 years & 29 & 19.73 \\
\hline 41 to 50 years & 30 & 20.41 \\
\hline 51 to 60 years & 30 & 20.41 \\
\hline > 60 years & 30 & 20.41 \\
\hline Total & 147 & 100.00 \\
\hline
\end{tabular}

Table 3 - General description of the sample and comparison of the right (RM) and left (LM) measurements

\begin{tabular}{|ccccccc|}
\hline $\begin{array}{c}\text { Vari- } \\
\text { able }\end{array}$ & N & $\begin{array}{c}\text { Aver- } \\
\text { age }\end{array}$ & Median & SD & $\begin{array}{c}\text { Mini- } \\
\text { mum }\end{array}$ & $\begin{array}{c}\text { Maxi- } \\
\text { mum }\end{array}$ \\
\hline Age & 147 & 45.07 & 44.00 & 14.96 & 18.00 & 73.00 \\
\hline RM & 147 & 102.89 & 104.20 & 10.23 & 54.40 & 122.20 \\
\hline LM & 147 & 102.58 & 103.30 & 10.87 & 59.90 & 129.50 \\
\hline
\end{tabular}

${ }^{*} \mathrm{RM}=$ measurement of the right mandibular notch angle; LM= measurement of the left mandibular notch angle. 
The Mann-Whitney test was applied to evaluate the relationship between the values of angular measurements and sexes (male and female). The results are displayed in Table 4.

Table 4 - Comparison between the values of the angular measurements and sexes (male and female)

\begin{tabular}{|cccccccccc|} 
Sex & Variable & N & Average & Median & SD & $\begin{array}{c}\text { Mini- } \\
\text { mum }\end{array}$ & $\begin{array}{c}\text { Maxi- } \\
\text { mum }\end{array}$ & p-value \\
\hline \multirow{2}{*}{ Female } & RM & 74 & 103.75 & 105.25 & 11.51 & 54.40 & 122.20 & 0.0837 \\
& LM & 74 & 102.80 & 103.55 & 11.93 & 59.90 & 129.50 & 0.7099 \\
\hline \multirow{2}{*}{ Male } & RM & 73 & 102.01 & 103.30 & 8.74 & 80.10 & 121.00 & \\
& LM & 73 & 102.36 & 102.70 & 9.75 & 71.70 & 122.80 &
\end{tabular}

Mann-Whitney test. ${ }^{*} \mathrm{RM}=$ measurement of the right mandibular notch angle; $\mathrm{LM}=$ measurement of the left mandibular notch angle.

It was noted that no statistically significant differences were found in the angles of the mandibular notches between the sexes.

The Kruskall-Wallis test was applied to establish the potential comparisons between the angular measurements of mandibular notches in the different age groups studied. The results are displayed in Table 5.

Table 5 - Comparison between the angular measurements and age groups in years.

\begin{tabular}{|c|c|c|c|c|c|c|c|c|}
\hline $\begin{array}{c}\text { Age } \\
\text { Group* }\end{array}$ & Variable & $\mathbf{N}$ & Average & Median & SD & $\begin{array}{l}\text { Mini- } \\
\text { mum }\end{array}$ & $\begin{array}{l}\text { Maxi- } \\
\text { mum }\end{array}$ & $\begin{array}{c}p- \\
\text { value }\end{array}$ \\
\hline \multirow{2}{*}{$18-30$} & $\mathrm{RM}$ & 28 & 98.51 & 101.95 & 13.17 & 54.40 & 117.50 & 0.0634 \\
\hline & LM & 28 & 99.15 & 99.85 & 11.91 & 59.90 & 121.40 & 0.3565 \\
\hline \multirow{2}{*}{$31-40$} & $\mathrm{RM}$ & 29 & 105.66 & 105.60 & 8.48 & 85.10 & 122.20 & \\
\hline & LM & 29 & 102.98 & 104.50 & 10.71 & 75.20 & 118.70 & \\
\hline \multirow{2}{*}{$41-50$} & $\mathrm{RM}$ & 30 & 102.18 & 104.65 & 11.12 & 75.40 & 121.00 & \\
\hline & LM & 30 & 102.67 & 103.10 & 10.40 & 75.80 & 117.90 & \\
\hline \multirow{2}{*}{$51-60$} & $\mathrm{RM}$ & 30 & 102.31 & 101.95 & 8.26 & 83.90 & 119.70 & \\
\hline & LM & 30 & 103.59 & 103.00 & 11.63 & 77.00 & 129.50 & \\
\hline \multirow{2}{*}{ »60 } & $\mathrm{RM}$ & 30 & 105.58 & 107.85 & 8.35 & 86.80 & 117.30 & \\
\hline & LM & 30 & 104.30 & 105.05 & 9.64 & 71.70 & 121.90 & \\
\hline
\end{tabular}

Kruskal-Wallis test. *RM = measurement of the right mandibular notch angle; $L M=$ measurement of the left mandibular notch angle.

The ANOVA for repeated measurements was used to assess their reproducibility. The data were transformed into ranks. The results are displayed in Table 6.
Table 6 - Evaluation of reproducibility (ANOVA test) LRA

\begin{tabular}{|ccccccc|}
\hline \multicolumn{2}{l}{ Descriptive: } & & & & \\
Variable & N & Average & Median & SD & $\begin{array}{c}\text { Minimum } \\
\text { Value }\end{array}$ & $\begin{array}{c}\text { Maximum } \\
\text { Value }\end{array}$ \\
\hline RM1 & 17 & 96.13 & 97.70 & 15.31 & 54.40 & 115.50 \\
\hline RM2 & 17 & 96.15 & 97.90 & 15.28 & 54.40 & 115.50 \\
\hline LM1 & 17 & 97.04 & 95.60 & 14.25 & 59.90 & 121.40 \\
\hline LM2 & 17 & 97.12 & 95.50 & 14.24 & 59.90 & 121.50 \\
\hline Comparisons & & & & & \\
\hline RM & & LM & & & & \\
\hline Factor & p-value & Factor & $p-$-value & & & \\
\hline LRA & 1.0000 & LRA & 0.0564 & & & \\
\hline
\end{tabular}

${ }^{*} \mathrm{LRA}=$ Left and Right Average

Reproducibililty was observed between repeated meansurements for RM and LM.

\section{DISCUSSION}

The imaging exams store characteristics of structures of individuals enabling measurements and analysis of these structures in search of data that may indicate whether, when evaluated, they might assist in the determination of sex and age. Among the various types of imaging exams, only a CT can provide three-dimensional images, and with a clarity and precision that enables safe and accurate measurements. As a result, this examination has become more and more frequently requested in clinical practice.

A computed tomography (CT) shows the depth of structures in slices in 3D images that better facilitate diagnosis and precise study than conventional panoramic radiographs that are two-dimensional. Some authors [2] reported that the CT is more interesting in the dentomaxillofacial region, for it shows less distortion of mineralized tissues, in addition to exposing the individual to a lower dose of radiation during the examination in comparison to panoramic radiography.

Dentistry plays an important role in the forensic area, assisting in identification in plane crashes, fires, accidents with multiple victims, investigations in criminal cases, and situations where only the bones of the skull and jaw are 
found. The bone structures of the skeleton are studied in order to observe their behavior and to indicate structures and reliable measurements for anthropological estimates, among them the age and sex.

The skull and the jaw are structures rich in information for forensic anthropology, in particular to forensic medicine and, consequently, to forensic dentistry, aiding in practices that look for characteristics to indicate the identity. With this in mind, studies were carried out [3] on nasal bones and the pyriform aperture in dry skulls that evidenced a significant sexual dimorphism. In addition to this, another study [1] was conducted to verify sexual dimorphism through the evaluation of posterior flexion of the mandibular ramus and stated that this flexion can be regarded as an additional feature of anthropological studies for determination of sex. Another study [6] analyzed the gonial angle in relation to age, sex, and dentition with radiographic and anthropometric methods; it affirmed that the angle examined is considered an additional parameter for forensic practice in determining sex. In the present study, the opening of the mandibular notch was evaluated to verify whether this structure could be an auxiliary component for determining sex and age.

Among the bones of the craniofacial skeleton, the mandible is known for being a highly resistant and durable bone, furthermore, it presents remarkable morphological characteristics of sexual dimorphism [7]. The masculine jaw is more robust and has more accentuated ridges for muscular insertions, besides presenting a greater weight when compared with the female jaw, which in turn is less robust with less pronounced ridgesmorphological characteristics that help in the differential diagnosis, but are not measurable data [8].

A study was conducted [9] in which an observational assessment was made of isolated mandibles belonging to the collection of a university-for verification of sex, considering the robustness of the inserts, mental tuberosity, and mandibular weight-and concluded that these morphological characteristics may contribute to forensic science.

It was observed in the literature that a large portion of the studies considered morphological characteristics, a fact that bolsters studies in search of somatometric data that may be reliable indicators of sex, since osteometric measurements possess a high level of reproducibility-important characteristics in regards to a scientific or legal context [10].

The literature contains a study [11] emphasizing the fact that craniometry is a good tool for identification, but which has a great disadvantage: the morphological and metric variables that occur in different populations due to climatic, dietary, and social organizational factors-reasons why regionalized studies are of extreme importance for the effectiveness of analyses. This study focused on the CTs of individuals in the city of São José dos Campos, the Paraíba Valley region, in the state of São Paulo.

As previously stated, the present study evaluated the mandibular notch angle as a possible tool to determine sexual dimorphism and age. The mandibular notch was analyzed by means of CT, considering the following points: the anteriormost point of the condylar process of the mandible, the posteriormost point of the coronoid process of the mandible, and the lowest point of the mandible notch-these vertices forming the opening of the notch, making the analysis possible.

In the literature there are other studies evaluating structures as determinants of sexual dimorphism through the assessment of CTs [4] that evaluated the dimensions of the TMJ in three-dimensional virtual models seeking to correlate the dimensions of the mandibular condyle with sex and age. The authors observed that the latero-medial measurements of the mandibular condyles showed statistically significant differences between sexes. Also considering the search for differences between 
sexes, [12] another study evaluated the foramen magnum [13] and other cranial measurements and achieved an accuracy of $90.7 \%$ in male identification and $73.3 \%$ in female.

With the objective of developing a new method for determining sex, measurements of the endocranial cavity were carried out [14] through 3D reconstruction and it was observed that the maximum width of the basilar part of the occipital bone, the maximum width of the foramen magnum, and the maximum distance between the oval foramina indicated sexual dimorphism. However, these results did not corroborate those of the present study where a frequency of 73 for males and 74 for females was observed, showing that there was no statistically significant structural difference between sexes. Results that corroborate those found by another study [15], evaluating the lateral angle of the temporal bone and the base of the skull, observed that there was no accuracy for determination of sex through the evaluation of these structures.

When analyzing the measurements of the right and left notches-with the right-side average for females of 103.75 , a maximum value of 122.20 and a minimum of 54.40 , and with the left-side average of 102.80 , a maximum value of 129.50 and a minimum of 59.90 - it was seen that the discrepancy of values between sides showed no significant difference and could not be estimated due to their values being too close together. In the same way, males had a right-side average of 102.01, with a maximum value of 121.00 and a minimum of 80.10 , and a left-side average of 102.36 , with a maximum value of 122.80 , and a minimum of 71.70 .

Given the results obtained in this study, it was observed that there were no pattern differences between sexes nor between measurements of the left and right sides.

The mandible undergoes structural and morphological changes during the course of growth, dental development, and occlusion, engendering bone remodeling with age. In a newborn, the body of the mandible has an obtuse mandibular angle-short and wide rami and a relatively large condylar process in relation to the rest of the bone structure. With the arrival of the deciduous dental elements, and the consequent onset of masticatory function, there is an increase in the height of the mandibular body, enlargement of the base of the mandible, and an increase of the rami, making the mandibular angles less obtuse. Mandibular growth and remodeling accompany the dental evolution-the replacement of the deciduous elements by permanent ones, and the development of occlusion. In the jaws of the edentulous there is an increase in the slope of the condylar process that results in the expansion of the mandibular notch [15]. These changes pose a hypothesis that data from the study of anatomical structures could delimit the age bracket with some degree of reliability, leading researchers to examine the behavior of these structures in order to estimate age.

One study [16] examined the gonial angle, the height of the mandibular ramus, and the bigonial width by means of panoramic radiographs to investigate the influence of differences in age and sex; they observed statistically significant differences in the mandibular morphology.

For the purposes of this study, five age groups were considered: from 18 to 30 years, 31 to 40 years, 41 to 50 years, 51 to 60 years, and above 60 years with a frequency of 28,29 , 30,30 and 30, respectively, and showed a slight increase between the age groups in general. In analyzing the angular measurements of the right and left mandibular notches, an increase was observed in accordance with the averages from the age groups, with a tendency of the angle of the mandibular notch to become slightly more obtuse. However, with a discrepancy in values between 31 and 40 years it is inconclusive to follow a solid pattern of estimation. These results were different than what was observed by other authors [4], who correlated the dimensions of the mandibular condyle with age bracket by means of three-dimensional models obtained by CT image and observed statistically significant changes in the age bracket between 31 and 
40 years-something that was not confirmed in the group above 60 years. Those authors suggested that this was due to the morphological degenerations caused by physiological aging.

In the forensic field, the study of anthropometric characteristics is of vital importance in solving problems related to identification and documentation. Studies that evaluated the mandibular notch in order to estimate age and sexual prediction were not found in the literature.

\section{CONCLUSION}

Based on the results obtained here, it was concluded that measuring the opening of the mandibular notch angle (MNA) was not useful in estimating age and sex in forensic anthropology.

\section{REFERENCES}

1. Shivaprakash S, Vijaykumar AG. Sex Determination BY Using Mandibular Ramus Posterior Flexure - A Prospective Study. Int J Health Sci Res. 2014;4(1):155-9.

2. Garib DB, Raymundo Júnior R, Raymundo MV, Raymundo DV, Ferreira SN. Tomografia computadorizada de feixe cônico (cone beam): entendendo este novo método de diagnóstico por imagem com promissora aplicabilidade na ortodontia. RDental Press Ortodon Ortop Facial. 2007;12(2):139-56.

3. Asghar A, Dixit A, Rani M. Morphometric study of nasal bone and pririform aperture in human dry skull of Indian origin. J Clin Diagn Res. 2016 Jan;10(1):AC05-7.doi: 10.7860/JCDR/2016/15677.7148. Epub2016 Jan1.

4. França C, Cunha HM, Barbieri AA, Assis ACS, Manhães Júnior LR, Lopes SPC. TMJ dimensions in three-dimensional virtual models acquired through computed tomography of cone beam as sexual dimorphism. Braz Dent Sci. 2017;20(3):34-43.
5. Instituto Brasileiro de Geografia e Estatística. Censo Demográfico 2010; Características da população e dos domicílios: resultados do universo. Rio de Janeiro:IBGE; 2011

6. Upadhyay RB, Upadhyay J, Agrawal P,Rao NN. Analysis of gonial angle in relation to age, gender, and dentition status by radiological and anthropometric methods. J Forensic Dent Sci. 2012;4(1):197-202

7. França GV. Medicina Legal. 8 ed. Rio de Janeiro: Guanabara Koogan SA;2008

8. Vanrell JP.Odontologia Legal e Antropologia Forense.2 ed. Rio de Janeiro: Guanabara Koogan,2009

9. Ferraz, RRN, CruzJB, CostaAG, Rodrigues FSM, ErrantePR. Provável classificação por gênero e estimativa de etnia de mandíbulas humanas isoladas. Revista UNILUSE Ensino e Pesquisa. 2015;12(26):31-5.

10. UrbanováP,Ross AH, Jurda M, Nogueira MI. Testing the reliability of software tools in sex and ancestry estimation in a multi-ancestral Brazilian sample. Leg Med (Tokyo).2014 Sep;16(5):264-73. doi: 10.1016/.legalmed.2014.06.002. Epub 2014 Jun 16.

11. Almeida Júnior E, Reis FP, Galvão LCC, Alves MC, Cabral ARJ, TeixeiraS. Estimativa do sexo e idade por meio do índice transverso em crânios secos de adultos. Rev Bahiana Odontol. 2013;4(2):85-95.

12. Uthman AT,Al-Rawi,Al-Timimi AFEvvaluation of maxillary sinus dimensions in gender determination using helical CT scanning.J Jorensic Sci. 2011;56(2):4038.

13. Tambawala SS, Karjodkar FR, Sansare K, Prakash N, Dora AC. Sexual dimorphism of foramen magnum using Cone Beam Computed Tomography. J Forensic Leg Med. 2016 Nov:44:29-34. doi: 10.1016/j.jflm.2016.08.005. Epub 2016 Aug 26.

14. Isaza J, Díaz CA, Bedoya JF, Monsalve T, Botella MC. Assessment of sex from endocranial cavity using volume-rendered CT scans in a sample from Medellín, Colombia. Forensic Sci Int. 2014 Jan;234:186.et-10. doi:10.1016/j. forsciint2013.10.023. Epub 2013 0ct31.

15. Duquesnel Mana M, Adalian P, Lynnerup N. Lateral angle and cranial base sexual dimorphism: a morphometric evaluation using computerised tomography scans of a modern documented autopsy population from Denmark. Anthropol Anz. 2016;73(2). doi: 10.1127/anthranz/2016/0424. Epub 2016 Mar 15.

16. Shamoud RA, Ammoush M, Alrbata R, Habahbah AA. Age and gender differences in gonial angle, ramus height and bigonial width in dentate subjects. Pakistan Oral Dent J. 2012;32(1):81-7.

\section{Sérgio Lúcio Pereira de Castro Lopes}

(Corresponding address)

Avenida Eng. Francisco José Longo, n 777

Jardim São Dimas - CEP - 12245-000

São José dos Campos, SP

Date submitted: 2018 Jul 12

e-mail: sergio.lopes@fosjc.unesp.br Accept submission: 2018 0ct 09 